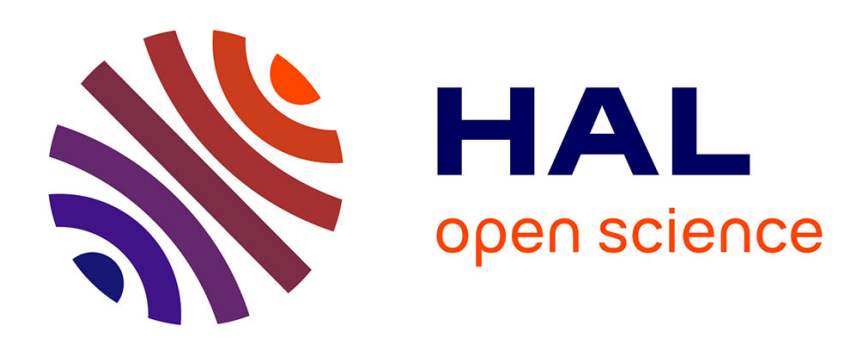

\title{
Different collagen types define two types of idiopathic epiretinal membranes
}

Michaela Kritzenberger, Benjamin Junglas, Carsten Framme, Horst Helbig, Veit-Peter Gabel, Rudolf Fuchshofer, Ernst R Tamm, Jost Hillenkamp

\section{- To cite this version:}

Michaela Kritzenberger, Benjamin Junglas, Carsten Framme, Horst Helbig, Veit-Peter Gabel, et al.. Different collagen types define two types of idiopathic epiretinal membranes. Histopathology, 2011, 58 (6), pp.953. 10.1111/j.1365-2559.2011.03820.x . hal-00631272

\section{HAL Id: hal-00631272 \\ https://hal.science/hal-00631272}

Submitted on 12 Oct 2011

HAL is a multi-disciplinary open access archive for the deposit and dissemination of scientific research documents, whether they are published or not. The documents may come from teaching and research institutions in France or abroad, or from public or private research centers.
L'archive ouverte pluridisciplinaire HAL, est destinée au dépôt et à la diffusion de documents scientifiques de niveau recherche, publiés ou non, émanant des établissements d'enseignement et de recherche français ou étrangers, des laboratoires publics ou privés. 


\section{Histopathology}

\section{Different collagen types define two types of idiopathic epiretinal membranes}

\begin{tabular}{|c|c|}
\hline Journal: & Histopathology \\
\hline Manuscript ID: & HISTOP-02-10-0101.R1 \\
\hline Wiley - Manuscript type: & Original Article \\
\hline $\begin{array}{r}\text { Date Submitted by the } \\
\text { Author: }\end{array}$ & 26-Jul-2010 \\
\hline Complete List of Authors: & $\begin{array}{l}\text { Kritzenberger, Michaela; University of Regensburg, Institute of } \\
\text { Human Anatomy and Embryology } \\
\text { Junglas, Benjamin; University of Regensburg, Institute of Human } \\
\text { Anatomy and Embryology } \\
\text { Framme, Carsten; University Eye Hospital Bern, Inselspital } \\
\text { Helbig, Horst; University of Regensburg, Department of } \\
\text { Ophthalmology } \\
\text { Gabel, Veit-Peter; University of Regensburg, Department of } \\
\text { Ophthalmology } \\
\text { Fuchshofer, Rudolf; University of Regensburg, Institute of Human } \\
\text { Anatomy and Embryology } \\
\text { Tamm, Ernst; University of Regensburg, Institute of Human } \\
\text { Anatomy and Embryology } \\
\text { Hillenkamp, Jost; University Medical Center Schleswig-Holstein, } \\
\text { Campus Kiel }\end{array}$ \\
\hline Keywords: & $\begin{array}{l}\text { extracellular matrix, ocular pathology, immunogold labeling, } \\
\text { electron microscopy }\end{array}$ \\
\hline
\end{tabular}

\section{SCHOLARONE Manuscripts}




\section{Different collagen types define two types of idiopathic epiretinal membranes}

Michaela Kritzenberger, ${ }^{1}$ Benjamin Junglas, ${ }^{1}$ Carsten Framme, ${ }^{2,3}$ Horst Helbig, ${ }^{2}$ Veit-Peter Gabel, ${ }^{2}$ Rudolf Fuchshofer, ${ }^{1}$ Ernst R. Tamm, ${ }^{1}$ Jost Hillenkamp ${ }^{4}$

Institute of Human Anatomy and Embryology ${ }^{1}$ and Department of Ophthalmology ${ }^{2}$, University of Regensburg, Germany, Department of Ophthalmology, University Medical Center SchleswigHolstein, Campus Kiel, Germany ${ }^{4}$

${ }^{3}$ present address at University Eye Hospital Bern, Inselspital, Switzerland

Running title: Collagen in epiretinal membranes

Keywords: Immunogold Techniques, Immunohistochemistry, Collagen Type III, Collagen Type VI, Epiretinal Membrane, Western Blotting, Transmission Electron Microscopy

Address for correspondence:

Ernst R. Tamm

Institute of Human Anatomy and Embryology

University of Regensburg

Universitätsstr. 31

D-93053 Regensburg

Tel.: +49-941-943-2839

Fax: +49-941-943-2840

Email: ernst.tamm@vkl.uni-regensburg.de 
Kritzenberger et al.: Collagen in epiretinal membranes

\section{Abstract}

Aims: To identify differences in extracellular matrix contents between idiopathic epiretinal membranes (IEM) of cellophane macular reflex (CMRM) or preretinal macular fibrosis (PMFM) type.

Methods and results: IEM were analyzed by light and quantitative transmission electron microscopy, immunohistochemistry, and Western blotting. Substantial differences between CMRM and PMFM were observed regarding the nature of extracellular fibrils. In CMRM, the fibrils were thin with diameters between 6-15 nm. Between the fibrils, aggregates of long-spacing collagen were observed. In PMFM, the diameters of fibrils measured either 18-26 nm or 36-56 $\mathrm{nm}$. By immunogold electron microscopy, 6-15 nm fibrils in CMRM were labeled for collagen type VI, while the fibrils in PMFM remained unstained. By Western blotting and immunohistochemistry, a strong signal for collagen type $\mathrm{VI}$ was observed in all CMRM, while immunoreactivity was weak or absent in PMFM. In contrast, PMFM showed immunoreactivity for collagen types I and II, which was weak or absent in CMRM. Both types of membranes showed immunoreactivity for collagen type III, IV, laminin and fibronectin with similar intensity.

Conclusion: The presence of high amounts of collagen type $\mathrm{VI}$ in CMRM and the relative absence of collagen types I and II is the major structural difference to PMFM.

Abbreviations: IEM, idiopathic epiretinal membranes; CMRM, cellophane macular reflex membrane; PMFM, preretinal macular fibrosis membrane; ILM, inner limiting membrane; ECM, extracellular matrix. 
Kritzenberger et al.: Collagen in epiretinal membranes

\section{Introduction}

Idiopathic epiretinal membranes (IEM) are caused by the migration of cells to the vitreoretinal junction and the formation of epimacular membranous tissue in the absence of any known underlying retinal disease. The processes that characterize IEM formation such as cell migration, and deposition and contraction of extracellular matrix show marked similarities to those which characterize wound healing at other sites in the body. ${ }^{1}$ Accordingly, IEM formation can be interpreted as an aberrant wound healing process at the vitreoretinal junction. The prevalence of the entity is high in the elderly population. ${ }^{2-4}$ IEM are associated with a dysfunction of the macula, the area of high acuity vision, which is probably related to an impairment of the inner retinal layers. ${ }^{5}$ For quite some time, no generally accepted nomenclature or classification existed, and IEM were termed macular pucker, ${ }^{6,7}$ preretinal macular fibrosis, ${ }^{8}$ epiretinal fibrosis, ${ }^{9}$ premacular gliosis, ${ }^{10}$ surface wrinkling retinopathy, ${ }^{11}$ cellophane maculopathy, ${ }^{12}$ or fibrocellular epiretinal membranes. ${ }^{13}$ More recently, several epidemiological studies such the Beaver Dam Eye Study, ${ }^{3}$ the Blue Mountains Eye Study ${ }^{2,14}$ and the Los Angeles Latino Eye Study ${ }^{4}$ defined two major types of IEM distinguishing a less severe form termed "cellophane macular reflex" from a more severe form termed "preretinal macular fibrosis". The distinction is based on the funduscopic appearance where membranes of the cellophane macular reflex type (CMRM) present as transparent patch or patches of irregular increased reflection from the inner surface of the retina, while membranes of the preretinal macular fibrosis type (PMFM) have a more opaque, grayish or whitish appearance on the retinal surface. ${ }^{15,16}$ The reasons for the different funduscopic appearances are not entirely clear, as some histopathological analyses reported on a correlation between the biomicroscopic opacification of IEM and their collagen content, ${ }^{7}$ while others found essentially no correlation between membrane opacification and cellularity or collagen content of the membranes. ${ }^{13}$ Besides their variation in funduscopic appearance, IEM show quite a substantial variation in their biomechanical properties which, in our hands, becomes evident during the delicate surgical peeling maneuver that is required for their removal from the retinal surface. ${ }^{17} \mathrm{CMRM}$ that appear rather transparent and cellophane-like by funduscopy, are usually rather "easy to peel" and can be removed in one stable piece once an edge of the membrane has been successfully delaminated from the retinal surface. By contrast, PMFM that are rather opaque and whitish are usually relatively "difficult to peel". These 
membranes are comparatively unstable, can only be removed by repeatedly grasping of small fragments that consist of a rather soft material, and provide a greater risk of retinal damage during surgery. In the present study, we wanted to identify distinct molecular differences that could account for the different funduscopic and biomechanical properties of CMRM or PMFM. In a combined ultrastructural, immunocytochemical and biochemical approach, we could identify clear qualitative differences between CMRM and PMFM regarding the nature of their collagen fibrils. The qualitative differences provide an explanation for the different biomechanical properties, and indicate that different pathogenetic mechanisms contribute to the formation of CMRM and PMFM.

\section{Material and methods}

IEM were obtained during standard three port vitrectomy performed by experienced vitreo-retinal surgeons (CF, HH, VPG, JH). IEM were classified by the operating surgeon as either CMRM or PMFM according to the following criteria: CMRM appeared thin, transparent and cellophane-like upon funduscopy. During surgery, CMRM were "easy to peel", mechanically stable, and were removed in one piece. PMFM appeared thick, opaque, grayish or whitish upon funduscopy. During surgery, PMFM were "difficult to peel", mechanically unstable, removed in several fragments, and required repeated grasping during removal. For each IEM, the funduscopic criteria were assessed and documented before surgery. Only IEM which clearly fulfilled both the funduscopic and surgical criteria were included. Membranes were completely removed and processed for light and electron microscopy. A total number of 60 IEM were processed. 32 IEM (53\%) were classified as CMRM and 28 as PMFM (47\%). 
Kritzenberger et al.: Collagen in epiretinal membranes

Light and electron microscopy

18 membranes (9 PMFM and 9 CMRM) were processed for light and transmission electron microscopy. Membranes were fixed for several hours in one half strength Karnovsky's fixative (2\% paraformaldehyde/2.5\% glutaraldehyde). ${ }^{18}$ After rinsing in $0.1 \mathrm{M}$ cacodylate buffer, postfixation was accomplished in a mixture of $1 \% \mathrm{OsO}_{4}$ and $0.8 \%$ potassium ferrocyanide in 0.1 $\mathrm{M}$ cacodylate buffer for $2 \mathrm{~h}$ at $4^{\circ} \mathrm{C}$. Specimens were then dehydrated in a graded series of ethanol and embedded in Epon (Serva, Heidelberg, Germany). Semithin sections (1 $\mu \mathrm{m})$ were collected on uncoated glass slides and stained with methylene blue/azure II after Richardson et al. ${ }^{19}$ for light microscopy. Ultrathin sections were mounted on uncoated copper grids, stained with uranyl acetate and lead citrate $^{20}$ and examined on a Zeiss EM 10 A electron microscope.

Immunohistochemistry

20 (10 PMFM and 10 CMRM) membranes were fixed in 4\% paraformaldehyde for several hours and then carefully rinsed in $0.1 \mathrm{M}$ phosphate buffered saline (PBS), $\mathrm{pH}$ 7.4. After processing through a graded series of ethanol, specimens were immersed in xylene and embedded in Paraplast (Sherwood, St. Louis, Missouri, USA). Sections were mounted on uncoated glass slides and dewaxed in a graded series of ethanol and xylene. Immunohistochemistry was carried out in a moist chamber on sections surrounded by water repellent PAP-PEN (Science Service, Munich, Germany) according to the following protocol: (1) preincubation (45 min) with blocking buffer containing $10 \%$ fetal calf serum (Seromed, Munich, Germany), 10\% normal goat serum (Sigma-Aldrich, Munich, Germany), $0.8 \%$ TritonX-100, $0.8 \% \mathrm{NaCl}, 0.15 \%$ Timerosal in $0.08 \mathrm{M}$ Tris-buffer, $\mathrm{pH} 7.4$; (2) overnight incubation at $4{ }^{\circ} \mathrm{C}$ with $1: 100$ diluted primary antibody [collagen I (Calbiochem, Merck, Darmstadt, Germany), collagen II (Chemicon via Millipore, Schwalbach, Germany), collagen III (BioGenex, San Ramon, California, USA), collagen IV (Rockland via Biomol, Hamburg, Germany), collagen VI (Rockland), fibronectin (Chemicon), laminin (Chemicon)] in blocking buffer; (3) rinsing with Tris-buffered saline (TBS); (4) incubation (60 min) 
in the appropriate secondary antibody [1:100 goat anti-mouse alexa 546 or goat anti-rabbit biotinylated IgG followed by streptavidin coupled with alexa 555 (all from Invitrogen, Karlsruhe, Germany)] in blocking buffer; (5) rinsing as in step 3 and mounting in fluorescent mounting medium (DAKO Cytomation, Hamburg, Germany) supplemented with $10 \%$ Vector shield mounting medium containing DAPI (Vector via Linaris, Wertheim-Bettingen, Germany). Sections were analyzed on a Zeiss Axio Imager light microscope. Control sections were incubated with PBS instead of the primary antibody.

\section{Ultraimmunohistochemistry}

8 membranes (4 PMFM and 4 CMRM) were fixed in $4 \%$ paraformaldehyde overnight and thoroughly rinsed in cacodylate buffer. After a graded series of ethanol, specimens were embedded in LR-White (Science Service, Munich, Germany). Ultrathin sections were mounted on nickel grids. Immunocytochemistry was performed in a moist chamber according to the following protocol: (1) preincubation with blocking buffer containing $10 \%$ normal goat serum and $0.005 \%$ fresh water fish gelatin (Biotrend, Cologne, Germany) in $0.1 \mathrm{M} \mathrm{TBS}, \mathrm{pH} 7.6$; (2) Overnight incubation with primary antibodies (collagen IV: 1:50, collagen VI: 1:25, both from Rockland); (3) carefully rinsing with washing buffer (TBS supplemented with $0.2 \%$ acetylated bovine serum albumin (BSA-c; Biotrend) and 0.8\% NaCl); (4) incubation with $10 \mathrm{~nm}$ gold conjugated goat-anti-rabbit antibody (Aurion via Biotrend); (5) rinsing with washing buffer followed by TBS; (6) postfixation with $2.5 \%$ glutaraldehyde in TBS for $5 \mathrm{~min}$; (7) rinsing with TBS and $\mathrm{H}_{2} \mathrm{O}$; (8) staining with uranyl acetate. Sections were analyzed on a Zeiss EM10A electron microscope. Control sections were incubated with PBS instead of the primary antibody.

\section{Western Blot Analysis}

A total of 14 IEM (6 PMFM and 8 CMRM) were processed for Western blotting. To obtain protein extracts, $200 \mu \mathrm{l}$ of TRIzol (Invitrogen, Karlsruhe, Germany) was added to IEM followed by 
Kritzenberger et al.: Collagen in epiretinal membranes

homogenization with a Power Gen 125 (Fisher Scientific, Schwerte, Germany). Proteins were isolated according to the manufacturer's instructions and protein content was measured by comparing a dot blot stained with Sypro Ruby (BioRad, München, Germany) to a bovine serum albumin standard. Protein yield in four CMRM was too low to allow further processing. Proteins were separated by SDS-PAGE and transferred to PVDF membranes (Millipore; Billerica, MA, USA) by semi-dry blotting. Western Blot analyses were performed with specific antibodies as described previously. ${ }^{21}$ Antibodies were used as follows: rabbit anti-collagen type VI (1:500; Rockland), rabbit anti-collagen type III (1:500; Santa Cruz, California, USA) and chicken antirabbit IgG, coupled to horseradish peroxidase (1:2000; Santa Cruz). Collagen type VI western blotting was done first followed by stripping each membrane with Roti@-free stripping buffer (Carl Roth, Karlsruhe, Germany) according to the manufacturer's instructions. Stripped membranes were blocked again and collagen type III labeling was performed. Chemiluminescence was detected with the help of Immobilon ${ }^{\mathrm{TM}}$ Western HRP substrate (Millipore) on a LAS 3000 imaging workstation. The molecular mass of the detected bands was determined using appropriate software (AIDA Image analyzer; Raytest, Straubenhardt, Germany).

\section{Results}

While PMFM were separated from the retina in several fragments during surgery, CMRM were removed in one piece which formed numerous folds after histological processing (Fig. 1A). By light microscopy, CMRM consisted largely of three ordered layers: An incomplete inner cellular layer which was attached to an intermediate extracellular layer that stained only faintly with methylene blue/azur II (Fig. 1B), and an outer extracellular layer that stained more intense. By electron microscopy, the outer extracellular layer consisted of both fine filamentous and amorphous material with the typical ultrastructural characteristics of a basal lamina. The 
Kritzenberger et al.: Collagen in epiretinal membranes

intermediate extracellular layer contained bundles of extracellular fibrils (Fig. 1C, D). We concluded that the outer extracellular layer is comprised of parts of the inner limiting membrane (ILM), while the intermediate extracellular layer and the inner cellular layer had been formed during pathogenesis of the CMRM. The structural elements which formed the three ordered layers in CMRM were also found in specimens clinically classified as PMFM (Fig. 1E, F). However, in contrast to CMRM, cells and the two kinds of extracellular matrices did not form distinct ordered layers in PMFM. Fragments containing ILM material were usually found to be separated from fragments containing larger amounts of extracellular fibrils and associated cells (Fig. 1E, F).

\section{Diameters of extracellular fibers differ between membranes of cellophane macular reflex or preretinal macular fibrosis type}

In order to find structural differences that could account for the different biomechanical properties of both CMRM and PMFM, we investigated in more detail the ultrastructure of the extracellular matrix in the intermediate extracellular layer of both kinds of IEM. The intermediate extracellular layer of CMRM consisted of fibrils that formed a dense irregular network without any preferential spatial orientation (Fig. 2A). Upon higher magnification, the fibrils showed no obvious periodicity (Fig. 2B). Quantitative evaluation showed that the extracellular fibrils of the CMRM intermediate layer had diameters between 6-15 nm, with a mean diameter of $9.2 \pm 1.9$ nm (Fig. 3). In some samples, aggregates of fibrous long-spacing "zebra" collagen were observed among the 6-15 nm fibrils (Fig. 2F). Long-spacing collagen consisted of broad bands of electron-dense material, which were interrupted by electron-lucent areas containing fine fibrillar material at a periodicity of $80-100 \mathrm{~nm}$ (Fig. $2 \mathrm{H}$ ). The intermediate layer of PMFM did also contain numerous extracellular fibrils which appeared to be oriented at random. Quantitative measurements showed that the fibrils in PMFM were thicker than those observed in CMRM with a mean diameter of $30.8 \pm 10.2 \mathrm{~nm}$ (Fig. 3). In five of the seven samples, the fibrils showed 
Kritzenberger et al.: Collagen in epiretinal membranes

diameters between 18-26 nm, with the majority of the fibers having a diameter of $21 \mathrm{~nm}$ (Figs. 2E, C). In the remaining two specimen of PMFM, the extracellular fibrils in the intermediate layer were considerably thicker with diameters between 36-56 nm (Fig. 2G). Upon higher magnification, the $36-56 \mathrm{~nm}$ fibers showed the typical periodicity of collagen fibers (Fig. 2D).

\section{High amounts of collagen type VI characterize cellophane macular reflex type membranes}

Since electron microscopy had shown a distinct difference in diameters of extracellular fibrils between CMRM and PMFM, we hypothesized that different size fibrils might consist of different types of collagen. Since in multiple tissues in- and outside the eye, aggregates of long-spacing collagen surrounded by small diameter extracellular microfibrils have been observed in extracellular matrices that are rich in collagen type $\mathrm{VI},{ }^{22-30}$ we hypothesized that the intermediate layer of CMRM might contain high amounts of collagen type VI. To clarify this hypothesis, we performed immunohistochemistry for collagen type VI both in CMRM and PMFM samples. Indeed, a strong homogenous immunoreactivity for collagen type VI was observed in all 11 samples of CMRM that were investigated (Fig. 4A). In contrast, immunoreactivity for collagen type VI was weak, patchy and barely detectable in all 10 samples of PMFM that were investigated by immunohistochemistry (Fig. 4B). The results obtained by immunohistochemistry correlated with those obtained by Western blotting. A strong signal for collagen type VI was observed in all four CMRM that were investigated, while the signal was absent or barely detectable in the six PMFM that were processed for Western blotting (Fig. 4C). In contrast, a signal for collagen type III was obtained in both types of membranes with equal intensity (Fig. 4C). Differences between CMRM and PMFM were also observed regarding the distribution of collagen types I and II which form striated collagen fibrils in situ. Out of eleven CMRM samples that were investigated, only three showed faint immunoreactivity for collagen type I or type II, respectively (Table I), while the rest remained unstained. In contrast, staining for collagen types I, and II was more common in PMFM. Six out of ten samples showed moderate to intense 
immunoreactivity for collagen type I (Fig. 5A, Table I). Those samples that did not react with antibodies against collagen type I stained with antibodies against collagen type II (Fig. 5B) and vice versa (Table I). Only one sample showed intense immunoreactivity for both collagen type I and II. Extracellular molecules that are distinct components of the ILM such as collagen type IV and laminin could be detected in all samples of CMRM and PMFM that were investigated (Fig. 5E,F, Table I). The same was true for fibronectin (Fig. 5G, Table I) which is supposed to connect the ILM with the collagen fibrils of the vitreous. ${ }^{31}$ Control sections in which the primary antibody had been omitted did not show immunoreactivity (Fig. 5C, D), and the same was true when the sections were labeled with an unrelated rabbit antibody (against Ki67) at the same concentration (not shown). In summary, the data obtained by immunohistochemistry and Western blotting correlated markedly with those obtained by transmission electron microscopy. CMRM that contained small diameter fibrils and long-spacing collagen showed strong immunoreactivity for collagen type $\mathrm{VI}$ that was weak or absent in PMFM. In contrast, PMFM that contained thicker size fibrils with typical periodicity stained for collagens types I and II while immunoreactivity for these collagen types was almost absent in CMRM. Labeling for collagen IV, laminin and fibronectin in both CMRM and PMFM correlated with the finding of fine filamentous basal lamina material presumably of ILM origin. In order to confirm that the $6-15 \mathrm{~nm}$ extracellular fibrils in the intermediate layer of CMRM are composed of collagen type $\mathrm{VI}$, ultraimmunohistochemisty with immunogold-labeling was performed. In CMRM, the fibrils of the intermediate layer were distinctly labeled with antibodies directed against collagen type VI (Fig. 6A,B). Gold particles were aligned along and in the vicinity of 6-15 nm extracellular fibrils, but were essentially absent intracellularly (Fig. 6A), or in the adjacent parts of the ILM (Fig. 6C). In contrast, immunogoldlabeling for collagen type VI was considerably weaker in the intermediate layer of PMFM, and only very few gold particles were observed in this area (Fig. 6D). Immunogold-labeling for collagen type IV, which was used as a positive control, was observed in the ILM areas of both 
Kritzenberger et al.: Collagen in epiretinal membranes

CMRM and PMFM (Figs. 6E, F). Negative controls in which the primary antibody had been omitted remained unstained (Fig. 6G).

\section{Cells present in membranes of cellophane macular reflex or preretinal macular fibrosis type are not obviously different}

As the different types of collagens that were observed in the intermediate layers of CMRM and PMFM might derive from different types of cells in the adjacent cellular layers, we investigated their ultrastructural details. In both types of membranes, cells were either arranged as a single layer or multilayers consisting of two to three cellular sheets. Two types of cells predominated: Oval-shaped cells which contained dense bundles of 8-10 nm intermediate filaments, showed numerous cellular processes and resembled fibrous astrocytes (Fig. 7A,B), and flat myofibroblast-like cells (Fig. 7C) with bundles of $6 \mathrm{~nm}$ actin filaments and dense bodies in their cytoplasm (Fig. 7D). In CMRM, seven out of nine membranes contained fibrous astrocytes, while PMFM showed this cell type in five out of seven. Myofibroblast-like cells were found in 6 out of the nine CMRM, and in four out the seven PMFM. In places, the myofibroblast-like cells were separated from the intermediate extracellular layer by an incomplete basal lamina (Fig. 7E). In two cases (one PMFM and one CMRM) macrophage-like cells with an indented nucleus and secondary lysosomes in the cytoplasm were observed (Fig. 7F). None of the samples contained pigmented cells or cells with an epithelial phenotype. Overall, no distinct differences regarding the phenotype of cells in the cellular layer was found between CMRM and PMFM. 


\section{Discussion}

Based on the results of our study, we conclude that the two major types of IEM substantially differ regarding their collagenous fibrillar extracellular matrix. The presence of high amounts of 6-15 nm fibrils consisting of collagen type VI characterizes CMRM. In contrast, fibers of collagen types I and II are rare or absent in CMRM, but common in PMFM. This conclusion is based on data obtained by electron microscopy in conjunction with morphometry, by immunohistochemistry at the light- and electronmicroscopical level, and by Western blotting.

Collagen type $\mathrm{VI}$ is an ubiquitous extracellular matrix protein which typically forms networks of 6-15 nm microfibrils. ${ }^{23,29,32,33}$ Consistent with the presence of collagen type VI in CMRM is the observation of aggregates of fibrous long-spacing collagen between the 6-15 $\mathrm{nm}$ microfibrils. Aggregates of fibrous long-spacing collagen have been found in various tissues in and outside the eye and have been shown to consist of collagen type $\mathrm{VI}$ fibrils. ${ }^{23,}{ }^{34}$ Collagen type VI fibrils form cross-banded fibrillar aggregates through end-to-end longitudinal assembly and overlapping. ${ }^{35}$ Alignment of the aggregates generates fibrous long-spacing collagen. ${ }^{25,34}$ It is of interest to note that already in early studies on the ultrastructure of eyes with subtle IEM, aggregates of long-spacing collagen were observed in the ECM of the membranes. ${ }^{36}$ In the absence of tools to identify the true nature of collagen fibrils, the surrounding fibrils were regarded at that time as "vitreous fibrils".

In addition to collagen type VI, CMRM showed strong immunoreactivity for collagen type IV, laminin, and fibronectin, three proteins that are constitutively found in the ILM $^{37}$ which had been invariably removed together with the membranous tissue in all CMRM that were investigated. Collagen fibrils that were considerably thicker than the 6-15 nm collagen type VI microfibrils were not observed in CMRM, but were commonly seen in PMFM. The thicker collagen fibrils in PMFM consisted of two groups of fibrils with diameters ranging from 19-28 nm 
Kritzenberger et al.: Collagen in epiretinal membranes

to $37-55 \mathrm{~nm}$. It is reasonable to assume that both groups of fibrils were identical with those that strongly labelled for collagen types I or II in the PMFM samples that were investigated by immunohistochemistry, although we did not perform immunogold labelling to confirm this. Only three out of 11 CMRM samples that were investigated showed weak immunoreactivity for collagen types I and II, while the others were essentially unlabeled strongly indicating that the relative amounts of collagen types I and II are very low in CMRM as compared to PMFM. In addition to collagen types I, and III, PMFM did also label with antibodies against collagen type IV, laminin and fibronectin corroborating findings of previous studies. ${ }^{38-45}$ PMFM did also contain some collagen type VI microfibrils that were labelled with immunogold between the thicker collagen fibrils of different nature. Still, the combined results of immunohistochemistry, immunogold labelling and Western blotting clearly indicate that collagen type VI microfibrils are less numerous in PMFM than in CMRM.

Networks of type VI collagen fibrils are present in basically all connective tissues and are typically found in close association with basement membranes. There is considerable evidence that type VI collagen functions to anchor basement membranes through strong interaction with type IV collagen. ${ }^{24,46-48}$ Collagen type VI also interacts with several other extracellular matrix constituents in vitro, including the fibrillar collagens type I and II. ${ }^{49} 50$ By light microscopy, immunostaining for collagen type VI has been observed at the vitreoretinal junction of normal eyes, ${ }^{37}$ and it appears to be reasonable to assume that collagen type $\mathrm{VI}$ contributes to anchor vitreous collagen type II fibrils to the ILM. ${ }^{37,38}$ To our knowledge, an age-related increase in the amounts of collagen type $\mathrm{VI}$ in the vitreoretinal junction of normal eyes has not been studied so far; neither by transmission electron microscopy nor by biochemical methods. Still, data from studies which compared the ultrastructure of the extracellular matrix at the vitreoretinal junction between normal eyes and those with IEM strongly indicate that the increase in collagen in the intermediate layer of CMRM is not an age-related phenomenon, but part of the pathological 
processes during CMRM formation. We hypothesize that excess collagen type $\mathrm{VI}$ in the intermediate layer of CMRM is the molecular reason for the high biomechanical stability of the membranes during surgical removal. Collagen type VI fibrils in the intermediate layer of CMRM should firmly attach to collagen type IV in the ILM (Fig. 7) which is peeled from the retinal surface along with the CMRM during surgery. In contrast, the ECM in the intermediate layer of PMFM which contains less collagen type VI should be less firmly attached to the ILM and may easily break during surgery.

It seems reasonable to assume that the ECM in the intermediate layer of both CMRM and PMFM is secreted and synthesized by cells in the immediate adjacent cellular layer. In our material, cells with a glia- or astrocyte-like, or a myofibroblast-like ultrastructure were predominant in both types of membranes, a finding that correlates with those of previous investigations on the ultrastructure of epiretinal membranes. ${ }^{7,51-56}$ Based on ultrastructural criteria alone, we did not find evidence for the presence of retinal pigmented epithelial cells in our material. Myofibroblast-like cells comprise most likely the cell type in epiretinal membranes which is responsible for their contraction. ${ }^{57}$ Both astrocytes and Müller cells have been shown to be capable of dedifferentiation to a mesenchymal myofibroblast-like phenotype under certain in vivo and vitro conditions, ${ }^{58-64}$ and may well do so in epiretinal membranes as cells with a mixed astrocyte/myofibroblast-like phenotype have been observed in vitreous membranes. ${ }^{56,65,66}$ Both astrocytes and Müller cells are capable of secreting collagen type VI, and the other ECM molecules that were observed in both CMRM and PMFM. ${ }^{67-69}$

During a five-year period, $9.3 \%$ of patients enrolled in the Blue Mountains Eye Study progressed from CMRM to PMFM. ${ }^{14}$ In CMRM, IEM cells appear to primarily secrete collagen type VI, a molecule that is also normally secreted by retinal glial cells. In contrast, in PMFM, IEM cells appear to primarily secrete collagen types I, II, III, which are normally not produced by 
Kritzenberger et al.: Collagen in epiretinal membranes

retinal glial cells, but by cells of a myofibroblast-like phenotype. During the progress from CMRM to PMFM, IEM cells may change their differentiation, and this change may account for the secretion of different types of collagens. TGF- $\beta$ signalling might be involved in this process, since TGF- $\beta$ is potent to induce myofibroblast-like phenotypes in glial cells, ${ }^{57,61}$ but also in a broad variety of other cell types..$^{70-75}$ While such a change in differentiation is a possible scenario, it needs to occur without major changes in the ultrastructural phenotypes of IEM cells, as we observed essentially the same types of cells in both CMRM and PMFM by transmission electron microscopy. A quantitative immunohistochemical characterization of the different types of IEM cells appears to be a requirement to support the concept of a change in differentiation of those cells that secrete the different collagen types in CMRM or PMFM. 


\section{References}

1. Midwood KS, Williams LV, Schwarzbauer JE. Tissue repair and the dynamics of the extracellular matrix. Int J Biochem Cell Biol 2004;36;1031-1037.

2. Mitchell P, Smith W, Chey T, Wang JJ, Chang A. Prevalence and associations of epiretinal membranes. The Blue Mountains Eye Study, Australia. Ophthalmology $1997 ; 104 ; 1033-1040$.

3. Klein R, Klein BE, Wang Q, Moss SE. The epidemiology of epiretinal membranes. Trans Am Ophthalmol Soc 1994;92;403-425; discussion 425-430.

4. Fraser-Bell S, Ying-Lai M, Klein R, Varma R. Prevalence and associations of epiretinal membranes in latinos: the Los Angeles Latino Eye Study. Invest Ophthalmol Vis Sci $2004 ; 45 ; 1732-1736$.

5. Tanikawa A, Horiguchi M, Kondo M, Suzuki S, Terasaki H, Miyake Y. Abnormal focal macular electroretinograms in eyes with idiopathic epimacular membrane. Am J Ophthalmol $1999 ; 127 ; 559-564$.

6. Tanenbaum HL, Schepens CL, Elzeneiny I, Freeman HM. Macular pucker following retinal detachment surgery. Arch Ophthalmol 1970;83;286-293.

7. Trese M, Chandler DB, Machemer R. Macular pucker. II. Ultrastructure. Graefes Arch Clin Exp Ophthalmol 1983;221;16-26.

8. Wise GN. Relationship of idiopathic preretinal macular fibrosis to posterior vitreous detachment. Am J Ophthalmol 1975;79;358-362.

9. Ciulla TA, Pesavento RD. Epiretinal fibrosis. Ophthalmic Surg Lasers 1997;28;670-679. 
Kritzenberger et al.: Collagen in epiretinal membranes

10. Appiah AP, Hirose T, Kado M. A review of 324 cases of idiopathic premacular gliosis. Am J Ophthalmol 1988;106;533-535.

11. Roth AM, Foos RY. Surface wrinkling retinopathy in eyes enucleated at autopsy. Trans Am Acad Ophthalmol Otolaryngol 1971;75;1047-1058.

12. Pournaras CJ, Donati G, Brazitikos PD, Kapetanios AD, Dereklis DL, Stangos NT. Macular epiretinal membranes. Semin Ophthalmol 2000;15;100-107.

13. Hiscott PS, Grierson I, McLeod D. Natural history of fibrocellular epiretinal membranes: a quantitative, autoradiographic, and immunohistochemical study. Br J Ophthalmol 1985;69;810823.

14. Fraser-Bell S, Guzowski M, Rochtchina E, Wang JJ, Mitchell P. Five-year cumulative incidence and progression of epiretinal membranes: the Blue Mountains Eye Study. Ophthalmology 2003;110;34-40.

15. Wise GN. Clinical features of idiopathic preretinal macular fibrosis. Schoenberg Lecture. Am J Ophthalmol 1975;79;349-347.

16. Jacobsen CH. Epiretinal membranes. Optom Clin 1996;5;77-94.

17. Hillenkamp J, Saikia P, Herrmann WA, Framme C, Gabel VP, Sachs HG. Surgical removal of idiopathic epiretinal membrane with or without the assistance of indocyanine green: a randomised controlled clinical trial. Graefes Arch Clin Exp Ophthalmol 2007;245;973-979.

18. Karnovsky MJ. A formaldehyde-glutaraldehyde fixative of high osmolality for use in electron-microscopy. J. Cell Biol. 1965;27;137-138.

19. Richardson KC, Jarret L, Finke H. Embedding in epoxy resins for ultrathin sectioning in electron microscopy. Stain Technol. 1960;35;313-323. 
Kritzenberger et al.: Collagen in epiretinal membranes

20. Reynolds ES. The use of lead citrate at high $\mathrm{pH}$ as an electron-opaque stain in electron microscopy. J Cell Biol 1963;17;208-212.

21. Fuchshofer R, Yu AH, Welge-Lüssen U, Tamm ER. Bone morphogenetic protein-7 is an antagonist of transforming growth factor-beta2 in human trabecular meshwork cells. Invest. Ophthalmol. Vis. Sci. 2007;48;715-726.

22. Bruns R. Beaded filaments and long spacing fibrils: Relation to type VI collagen. J. Ultrastruct. Res. 1984;89;136-145.

23. Tamm E, Jungkunz W, Marsch WC, Lütjen-Drecoll E. Increase in types IV and VI collagen in cherry haemangiomas. Arch. Dermatol. Res. 1992;284;275-282.

24. Bruns RR, Press W, Engvall E, Timpl R, Gross J. Type VI collagen in extracellular, 100$\mathrm{nm}$ periodic filaments and fibrils: identification by immunoelectron microscopy. J Cell Biol $1986 ; 103 ; 393-404$.

25. Knupp C, Pinali C, Munro PM et al. Structural correlation between collagen VI microfibrils and collagen VI banded aggregates. J Struct Biol 2006;154;312-326.

26. Knupp C, Amin SZ, Munro PM, Luthert PJ, Squire JM. Collagen VI assemblies in agerelated macular degeneration. J Struct Biol 2002;139;181-189.

27. Knupp C, Chong NH, Munro PM, Luthert PJ, Squire JM. Analysis of the collagen VI assemblies associated with Sorsby's fundus dystrophy. J Struct Biol 2002;137;31-40.

28. Oda $\mathrm{Y}$, Kawahara E, Minamoto T et al. Immunohistochemical studies on the tissue localization of collagen types I, III, IV, V and VI in schwannomas. Correlation with ultrastructural features of the extracellular matrix. Virchows Arch B Cell Pathol Incl Mol Pathol 1988;56;153163. 
Kritzenberger et al.: Collagen in epiretinal membranes

29. Rittig M, Tittor F, Lütjen-Drecoll E, Mollenhauer J, Rauterberg J. Immunohistochemical study of extracellular material in the aged human synovial membrane. Mech. Ageing Develop. $1992 ; 64 ; 219-234$.

30. Schlumberger W, Thie M, Rauterberg J, Kresse H, Robenek H. Deposition and ultrastructural organization of collagen and proteoglycans in the extracellular matrix of gelcultured fibroblasts. Eur. J. Cell Biol. 1989;50;100-110.

31. Kohno T, Sorgente N, Ishibashi T, Goodnight R, Ryan SJ. Immunofluorescent studies of fibronectin and laminin in the human eye. Invest. Ophthalmol. Vis. Sci. 1987;28;506-514.

32. Von der Mark H, Aumailley M, Wick G, Fleischmajer R, Timpl R. Immunochemistry, genuine size and tissue localization of collagen VI. Eur. J. Biochem. 1984;142;493-502.

33. Tamm E, Baur A, Lütjen-Drecoll E. Synthesis of extracellular matrix components by human ciliary muscle cells in culture. Curr. Eye Res. 1992;11;333-341.

34. Reale E, Groos S, Luciano L, Eckardt C, Eckardt U. In the mammalian eye type VI collagen tetramers form three morphologically different aggregates. Matrix Biol 2001;20;37-51.

35. Kuo H-J, Keene DR, Glanville RW. Orientation of type VI collagen monomeres in molecular aggregates. Biochemistry 1989;28;3757-3762.

36. Foos RY. Vitreoretinal juncture; epiretinal membranes and vitreous. Invest Ophthalmol Vis Sci 1977;16;416-422.

37. Ponsioen TL, van Luyn MJ, van der Worp RJ, van Meurs JC, Hooymans JM, Los LI. Collagen distribution in the human vitreoretinal interface. Invest Ophthalmol Vis Sci 2008;49;4089-4095. 
Kritzenberger et al.: Collagen in epiretinal membranes

38. Scheiffarth OF, Kampik A, Gunther H, von der Mark K. Proteins of the extracellular matrix in vitreoretinal membranes. Graefes Arch Clin Exp Ophthalmol 1988;226;357-361.

39. Okada M, Ogino N, Matsumura M, Honda Y, Nagai Y. Histological and immunohistochemical study of idiopathic epiretinal membrane. Ophthalmic Res 1995;27;118128.

40. Ioachim E, Stefaniotou M, Gorezis S, Tsanou E, Psilas K, Agnantis NJ. Immunohistochemical study of extracellular matrix components in epiretinal membranes of vitreoproliferative retinopathy and proliferative diabetic retinopathy. Eur J Ophthalmol $2005 ; 15 ; 384-391$.

41. Immonen I, Tervo K, Virtanen I, Laatikainen L, Tervo T. Immunohistochemical demonstration of cellular fibronectin and tenascin in human epiretinal membranes. Acta Ophthalmol (Copenh) 1991;69;466-471.

42. Jerdan JA, Pepose JS, Michels RG et al. Proliferative vitreoretinopathy membranes. An immunohistochemical study. Ophthalmology 1989;96;801-810.

43. Morino I, Hiscott P, McKechnie N, Grierson I. Variation in epiretinal membrane components with clinical duration of the proliferative tissue. Br J Ophthalmol 1990;74;393-399.

44. Grisanti S, Heimann K, Wiedemann P. Origin of fibronectin in epiretinal membranes of proliferative vitreoretinopathy and proliferative diabetic retinopathy. Br J Ophthalmol $1993 ; 77 ; 238-242$.

45. Casaroli Marano RP, Vilaro S. The role of fibronectin, laminin, vitronectin and their receptors on cellular adhesion in proliferative vitreoretinopathy. Invest Ophthalmol Vis Sci $1994 ; 35 ; 2791-2803$. 
Kritzenberger et al.: Collagen in epiretinal membranes

46. Kuo HJ, Maslen CL, Keene DR, Glanville RW. Type VI collagen anchors endothelial basement membranes by interacting with type IV collagen. J Biol Chem 1997;272;26522-26529.

47. Keene DR, Engvall E, Glanville RW. Ultrastructure of type VI collagen in human skin and cartilage suggests an anchoring function for this filamentous network. J Cell Biol 1988;107;19952006.

48. Senga $\mathrm{K}$, Kobayashi M, Hattori $\mathrm{H}$ et al. Type VI collagen in mouse masseter tendon, from osseous attachment to myotendinous junction. Anat Rec 1995;243;294-302.

49. Bonaldo P, Russo V, Bucciotti F, Doliana R, Colombatti A. Structural and functional features of the alpha 3 chain indicate a bridging role for chicken collagen $\mathrm{VI}$ in connective tissues. Biochemistry 1990;29;1245-1254.

50. Bidanset DJ, Guidry C, Rosenberg LC, Choi HU, Timpl R, Hook M. Binding of the proteoglycan decorin to collagen type VI. J Biol Chem 1992;267;5250-5256.

51. Kampik A, Green WR, Michels RG, Nase PK. Ultrastructural features of progressive idiopathic epiretinal membrane removed by vitreous surgery. Am J Ophthalmol 1980;90;797809.

52. Kampik A, Kenyon KR, Michels RG, Green WR, de la Cruz ZC. Epiretinal and vitreous membranes. Comparative study of 56 cases. Arch Ophthalmol 1981;99;1445-1454.

53. Messmer EM, Heidenkummer HP, Kampik A. Ultrastructure of epiretinal membranes associated with macular holes. Graefes Arch Clin Exp Ophthalmol 1998;236;248-254.

54. Rodrigues MM, Newsome DA, Machemer R. Further characterization of epiretinal membranes in human massive periretinal proliferation. Curr Eye Res 1981;1;311-315. 
55. Hiscott PS, Grierson I, Trombetta CJ, Rahi AH, Marshall J, McLeod D. Retinal and epiretinal glia--an immunohistochemical study. Br J Ophthalmol 1984;68;698-707.

56. Vinores SA, Campochiaro PA, Conway BP. Ultrastructural and electronimmunocytochemical characterization of cells in epiretinal membranes. Invest Ophthalmol Vis Sci 1990;31;14-28.

57. Bochaton-Piallat ML, Kapetanios AD, Donati G, Redard M, Gabbiani G, Pournaras CJ. TGF-beta1, TGF-beta receptor II and ED-A fibronectin expression in myofibroblast of vitreoretinopathy. Invest Ophthalmol Vis Sci 2000;41;2336-2342.

58. Guidry C, Bradley KM, King JL. Tractional force generation by human muller cells: growth factor responsiveness and integrin receptor involvement. Invest Ophthalmol Vis Sci 2003;44;1355-1363.

59. Guidry C. The role of Muller cells in fibrocontractive retinal disorders. Prog Retin Eye Res $2005 ; 24 ; 75-86$.

60. Guidry C, King JL, Mason JO. Fibrocontractive Muller cell phenotypes in proliferative diabetic retinopathy. Invest Ophthalmol Vis Sci 2008.

61. Moreels M, Vandenabeele F, Dumont D, Robben J, Lambrichts I. Alpha-smooth muscle actin (alpha-SMA) and nestin expression in reactive astrocytes in multiple sclerosis lesions: potential regulatory role of transforming growth factor-beta 1 (TGF-beta1). Neuropathol Appl Neurobiol 2008;34;532-546.

62. Abd-el-Basset EM, Fedoroff S. Immunolocalization of the alpha isoform of smooth muscle actin in mouse astroglia in cultures. Neurosci Lett 1991;125;117-120. 
Kritzenberger et al.: Collagen in epiretinal membranes

63. Lecain E, Alliot F, Laine MC, Calas B, Pessac B. Alpha isoform of smooth muscle actin is expressed in astrocytes in vitro and in vivo. J Neurosci Res 1991;28;601-606.

64. Buniatian GH, Gebhardt R, Mecke D, Traub P, Wiesinger H. Common myofibroblastic features of newborn rat astrocytes and cirrhotic rat liver stellate cells in early cultures and in vivo. Neurochem Int 1999;35;317-327.

65. Hara A. Myoastrocytes in vitreous membrane in nontraumatic giant retinal tear. Jpn J Ophthalmol 1985;29;177-186.

66. Smiddy WE, Green WR, Michels RG, de la Cruz Z. Ultrastructural studies of vitreomacular traction syndrome. Am J Ophthalmol 1989;107;177-185.

67. Ponsioen TL, van Luyn MJ, van der Worp RJ, Pas HH, Hooymans JM, Los LI. Human retinal Muller cells synthesize collagens of the vitreous and vitreoretinal interface in vitro. Mol Vis $2008 ; 14 ; 652-660$.

68. Fuchshofer R, Birke M, Welge-Lüssen U, Kook D, Lütjen-Drecoll E. Transforming growth factor-beta 2 modulated extracellular matrix component expression in cultured human optic nerve head astrocytes. Invest. Ophthalmol. Vis. Sci. 2005;46;568-578.

69. Neumann C, Yu A, Welge-Lussen U, Lutjen-Drecoll E, Birke M. The effect of TGF-beta2 on elastin, type $\mathrm{VI}$ collagen, and components of the proteolytic degradation system in human optic nerve astrocytes. Invest Ophthalmol Vis Sci 2008;49;1464-1472.

70. Tamm ER, Siegner A, Baur A, Lütjen-Drecoll E. Transforming growth factor- $\beta 1$ induces $\alpha$-smooth muscle-actin expression in cultured human and monkey trabecular meshwork. Exp. Eye Res. 1996;62;389-397. 
Kritzenberger et al.: Collagen in epiretinal membranes

71. Flügel-Koch C, Ohlmann A, Piatigorsky J, Tamm ER. Disruption of anterior segment development by TGF-beta1 overexpression in the eyes of transgenic mice. Dev Dyn $2002 ; 225 ; 111-125$.

72. Hales AM, Schulz MW, Chamberlain CG, McAvoy JW. TGF- $\beta 1$ induces lens cells to accumulate $\alpha$-smooth muscle actin, a marker for subcapsular cataracts. Curr.Eye Res. $1994 ; 13 ; 885-890$.

73. Gamulescu MA, Chen Y, He S et al. Transforming growth factor beta2-induced myofibroblastic differentiation of human retinal pigment epithelial cells: regulation by extracellular matrix proteins and hepatocyte growth factor. Exp Eye Res 2006;83;212-222.

74. Kurosaka H, Kurosaka D, Kato K, Mashima Y, Tanaka Y. Transforming growth factorbeta 1 promotes contraction of collagen gel by bovine corneal fibroblasts through differentiation of myofibroblasts. Invest Ophthalmol Vis Sci 1998;39;699-704.

75. Kurosaka D, Muraki Y, Inoue M, Katsura H. TGF-beta 2 increases alpha-smooth muscle actin expression in bovine retinal pigment epithelial cells. Curr Eye Res 1996;15;1144-1147. 
Kritzenberger et al.: Collagen in epiretinal membranes

\section{FIGURE LEGENDS}

Fig. 1. Light microscopy $(A, B, E)$ and low power electron microscopy (C, D, F) of CMRM (A-D), and PMFM (E, F). Light micrographs of semithin sections stained with methylene blue/ azur II. A, B: CMRM largely consist of three layers: A cellular layer (arrow), and two layers of extracellular matrix (asterisk and arrowheads). B is magnification of A. Scale bars: A. $10 \mu \mathrm{m}, \mathrm{B} .5 \mu \mathrm{m} . \mathrm{C}, \mathrm{D}$ : By electron microscopy, the intermediate extracellular layer contains bundles of extracellular fibrils (asterisks, higher magnification in $2 \mathrm{~A}$ and $\mathrm{B}$ ), while the outer extracellular layer (arrowheads) consists of fine filamentous material which the structural characteristics of the inner limiting membrane (ILM). D is magnification of C. Scale bars: C. $2 \mu \mathrm{m}$, D. $1 \mu \mathrm{m}$. E. In PMFM, fragments of ILM (arrowheads) are typically separated from cells (arrow) and intermediate extracellular layer (asterisk). Scale bar: $10 \mu \mathrm{m}$. F. By electron microscopy, dense bundles of collagen fibrils (asterisks) are found in the intermediate layer. Scale bar: $2 \mu \mathrm{m}$.

Fig. 2. Electron microscopy of 6-15 nm extracellular fibrils in CMRM (A, B), and of 18-26 nm fibrils $(E, C)$ and $36-56 \mathrm{~nm}$ fibrils $(G, D)$ in samples of PMFM. A, E, G, or B, C, D show the same magnification, respectively. Scale bars: $0.5 \mu \mathrm{m}(\mathrm{A}, \mathrm{E}, \mathrm{G})$ and $100 \mathrm{~nm}(\mathrm{~B}, \mathrm{C}, \mathrm{D}) .36-56 \mathrm{~nm}$ fibrils show the typical periodicity of collagen fibrils (arrowheads in D). F, H. Aggregates of fibrous long spacing collagen are found between the 6-15 nm fibrils of the intermediate extracellular layer in CMRM. Scale bars: $1 \mu \mathrm{m}(\mathrm{C}), 250 \mathrm{~nm}(\mathrm{D})$.

Fig. 3. Morphometric analysis of intermediate layer fibril diameter. A. mean $\pm S D$ of diameter of fibrils in CMRM $(n=5)$ and PMFM (n=7). B. distribution of fibril diameter. Measurements were taken from high (x75 000) magnification TEM micrographs and a total of 150 fibrils were randomly selected and measured in each specimen. 
Fig. 4. Immunohistochemistry for collagen type $\mathrm{VI}(\mathrm{A}, \mathrm{B})$ and Western blotting $(\mathrm{C})$ in proteins from CMRM and PMFM. Collagen type VI shows intense immunoreactivity in CMRM (A), but only moderate staining in PMFM (B).

Fig. 5. Immunohistochemistry in CMRM and PMFM. A. collagen I, B. collagen II, E. collagen IV, F. laminin, G. fibronectin (all in PMFM). C, D. Negative controls of secondary antibodies (C. goat anti-mouse, D. goat anti-rabbit) with omission of primary antibodies show only DAPI-staining of nuclei. Scale bar: $100 \mu \mathrm{m}$.

Fig. 6. Immunogold electron microscopy. A-D. Collagen VI. A. Strong expression for collagen VI is seen in the intermediate layer of CMRM, while cells remain unstained (right margin). B. Immungold particles specific for collagen type VI are associated with the 6-15 nm microfibrils in the CMRM. C. Immunoreactivity for collagen type VI is absent in the ILM of CMRM. D. In the intermediate layer of PMFM, only few immungold particles specific for collagen type VI are observed. E,F. Immunogold labeling for collagen type IV in the ILM of PMFM. G. Negative control of secondary antibody with omission of primary antibody. Scale bars $0.5 \mu \mathrm{m}(\mathrm{A}, \mathrm{E}), 1 \mu \mathrm{m}$ (e), $200 \mathrm{~nm}(\mathrm{~B}, \mathrm{C}, \mathrm{D}, \mathrm{F}, \mathrm{G})$.

Fig. 7. Electron micrographs of cells in the cellular layer of IEM. A, B. Fibrous astrocytes (A, scale bar: $2 \mu \mathrm{m}$; B. scale bar $0.5 \mu \mathrm{m}$ ) with numerous cellular processes (asterisks in B), and tightly packed intermediate filaments (arrowheads in B). C-E. Myofibroblast-like cells with elongated cells body and oval-shaped nucleus (C, scale bar: $2 \mu \mathrm{m})$, and 5-6 nm actin filaments (arrows) with dense bodies (arrowheads, scale bar $0.5 \mu \mathrm{m})$. Myofibroblast-like cells are surrounded by basal lamina (E, arrowheads, scale bar $1 \mu \mathrm{m})$. F. Macrophage-like cells in the intermediate layer with indented nuclei and secondary lysosomes, scale bar: $2 \mu \mathrm{m}$. 
Kritzenberger et al.: Collagen in epiretinal membranes

Fig. 8. Schematic drawing of the three-layered structure in CMRM. Collagen type VI fibrils in the intermediate layer (ILM) connect with collagen type IV in the inner limiting membrane (ILM) and with cells and their basal lamina in the cellular layer $(C L)$. 
Kritzenberger et al.: Collagen in epiretinal membranes

Table I. Immunohistochemistry, semiquantitative evaluation

Collagen I Collagen II Collagen IV Fibronectin Laminin

\begin{tabular}{|c|c|c|c|c|c|}
\hline \multirow[t]{10}{*}{ CMRM } & $(+)$ & & ++ & + & ++ \\
\hline & $(+)$ & & ++ & ++ & ++ \\
\hline & $(+)$ & $(+)$ & + & + & + \\
\hline & & & ++ & ++ & + \\
\hline & & & + & + & ++ \\
\hline & & & ++ & + & ++ \\
\hline & & & ++ & + & ++ \\
\hline & & & ++ & + & ++ \\
\hline & & & + & + & ++ \\
\hline & & & + & + & + \\
\hline \multirow[t]{10}{*}{ PMFM } & ++ & ++ & + & ++ & ++ \\
\hline & ++ & & + & ++ & + \\
\hline & + & & + & + & ++ \\
\hline & + & & + & + & ++ \\
\hline & $(+)$ & & + & ++ & $(+)$ \\
\hline & $(+)$ & & + & + & + \\
\hline & & + & + & ++ & ++ \\
\hline & & + & ++ & ++ & ++ \\
\hline & & + & ++ & + & + \\
\hline & & + & + & + & + \\
\hline
\end{tabular}

(+) patchy staining in some areas of the sample; + homogenous staining throughout the entire sample; ++ intense staining. 

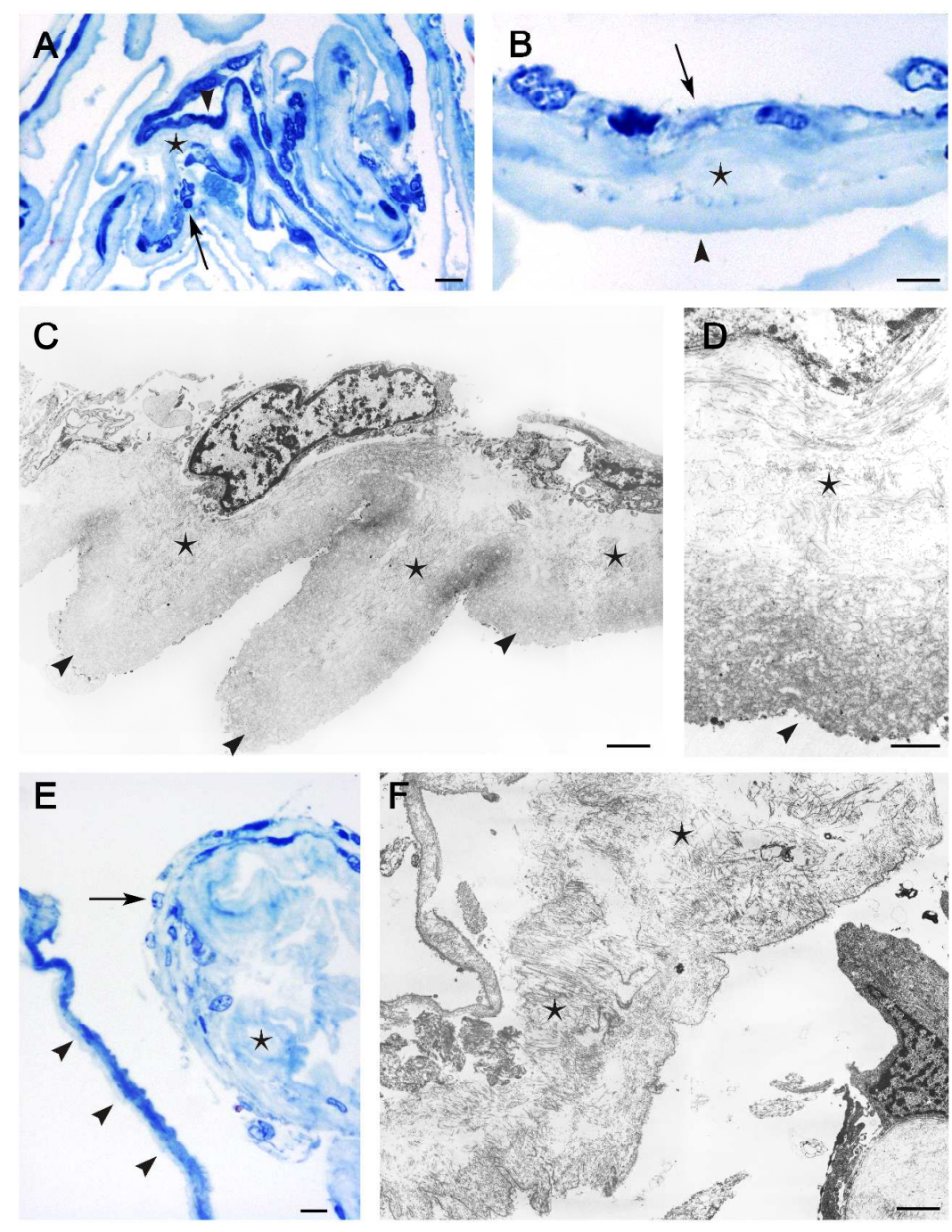

Fig. 1. Light microscopy (A, B, E) and low power electron microscopy (C, D, F) of CMRM (A-D), and $\operatorname{PMFM}(E, F)$. Light micrographs are stained with methylene blue/ azur II. A, B: CMRM largely consist of three layers: A cellular layer (arrow), and two layers of extracellular matrix (asterisk and arrowheads). B is magnification of A. Scale bars: A. $10 \mu \mathrm{m}$, B. $5 \mu \mathrm{m}$. C, D: By electron microscopy, the intermediate extracellular layer contains bundles of extracellular fibrils (asterisks), while the outer extracellular layer (arrowheads) consists of fine filamentous material which the structural characteristics of the inner limiting membrane (ILM). D is magnification of C. Scale bars: C. $2 \mu \mathrm{m}$, D. $1 \mu \mathrm{m}$. E. In PMFM, fragments of ILM (arrowheads) are typically separated from cells (arrow) and intermediate extracellular layer (asterisk). Scale bar: $10 \mu \mathrm{m}$. F. By electron microscopy, dense bundles of collagen fibrils (asterisks) are found in the intermediate layer. Scale bar: $2 \mu \mathrm{m}$. $180 \times 244 \mathrm{~mm}(600 \times 600 \mathrm{DPI})$ 

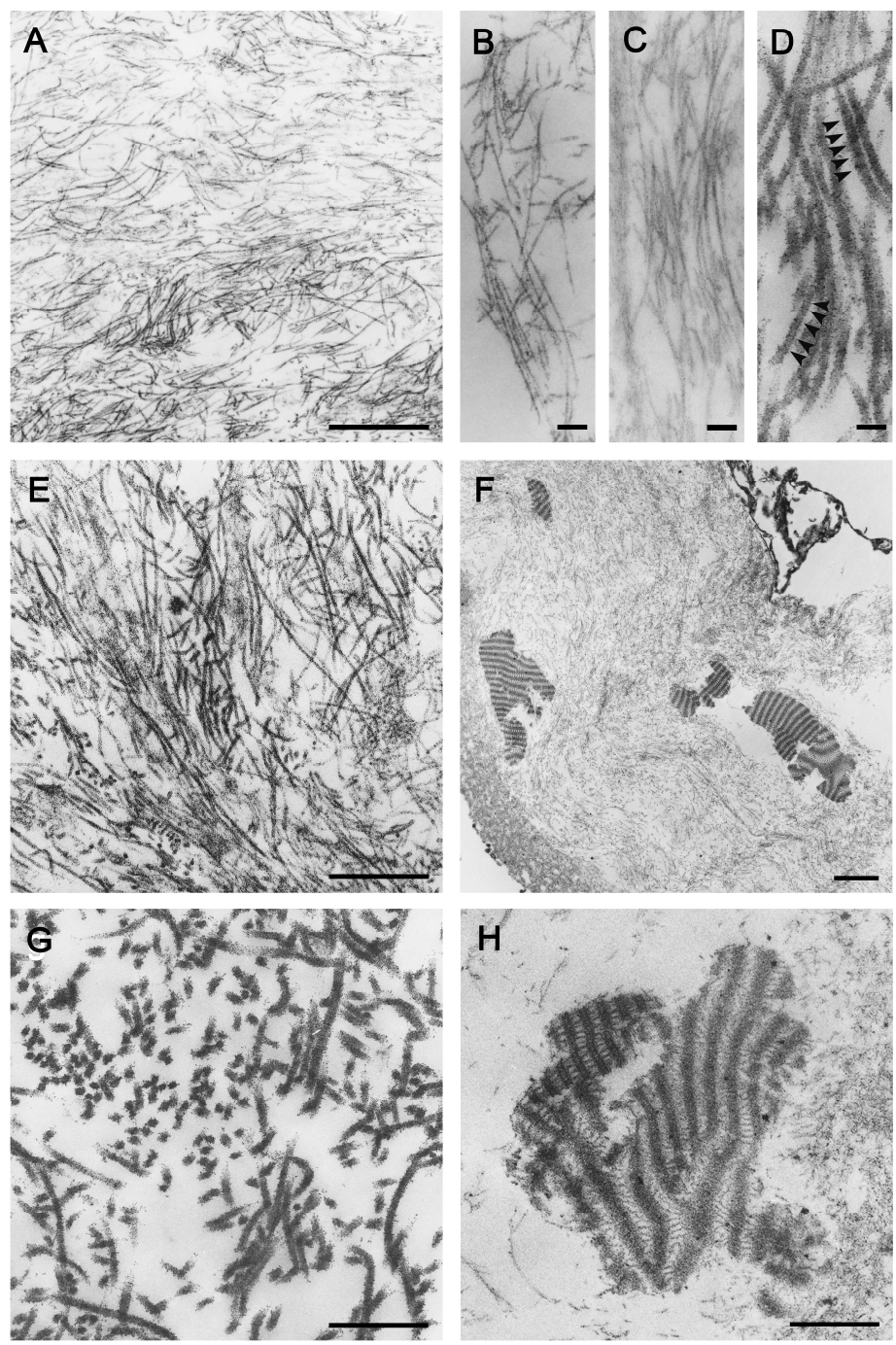

Fig. 2. Electron microscopy of 6-15 nm extracellular fibrils in CMRM (A, B), and of 18-26 nm fibrils $(E, C)$ and 36-56 nm fibrils (G, D) in samples of PMFM. A, E, G, or B, C, D show the same magnification, respectively. Scale bars: $0.5 \mu \mathrm{m}(A, E, G)$ and $100 \mathrm{~nm}(B, C, D) .36-56 \mathrm{~nm}$ fibrils show the typical periodicity of collagen fibrils (arrowheads in D). F, H. Aggregates of fibrous long spacing collagen are found between the 6-15 nm fibrils of the intermediate extracellular layer in CMRM. Scale bars: $1 \mu \mathrm{m}(\mathrm{C}), 250 \mathrm{~nm}(\mathrm{D})$. $180 \times 280 \mathrm{~mm}(600 \times 600 \mathrm{DPI})$ 

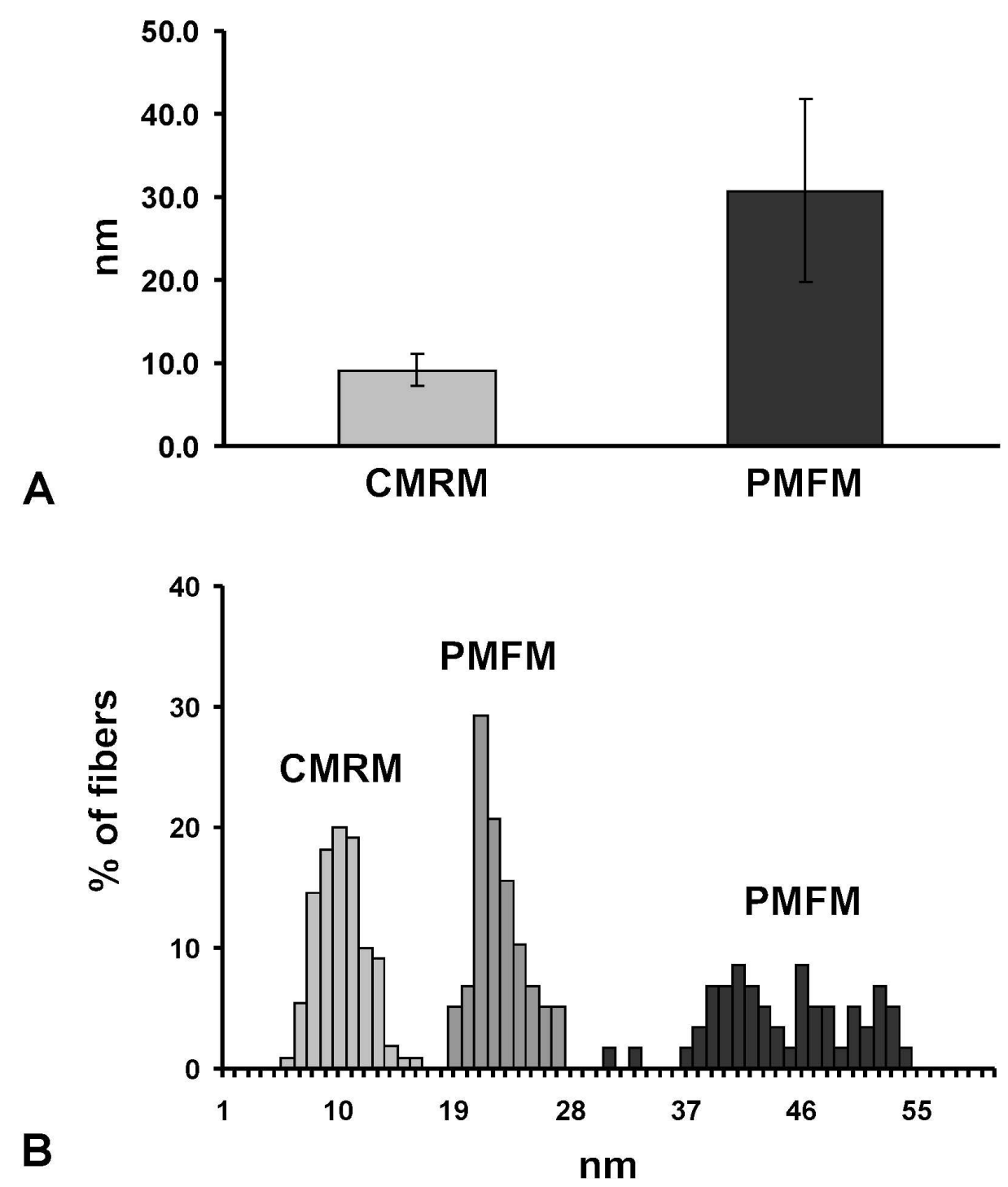

Fig. 3. Morphometric analysis of intermediate layer fibril diameter. A. mean \pm SD of diameter of fibrils in CMRM $(n=5)$ and PMFM $(n=7)$. B. distribution of fibril diameter. Measurements were taken from high (x75 000) magnification TEM micrographs and a total of 150 fibrils were randomly selected and measured in each specimen. 

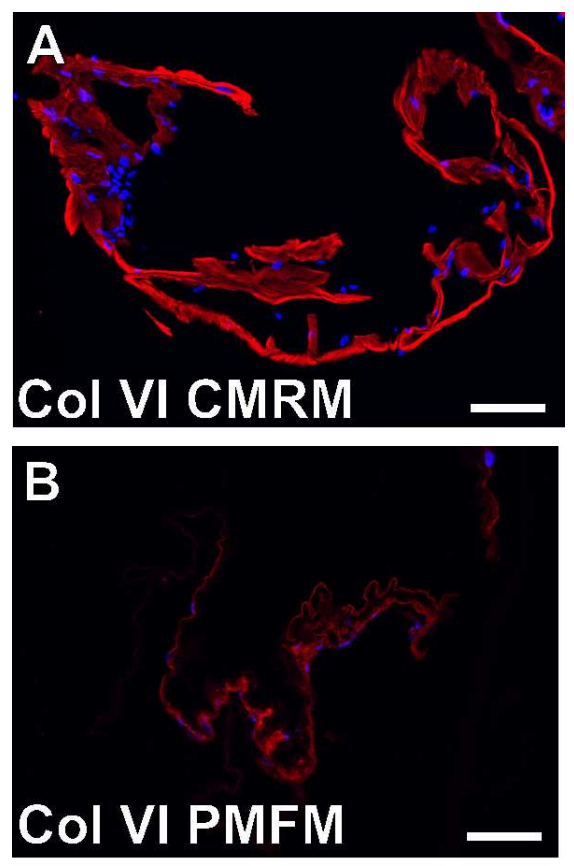

C

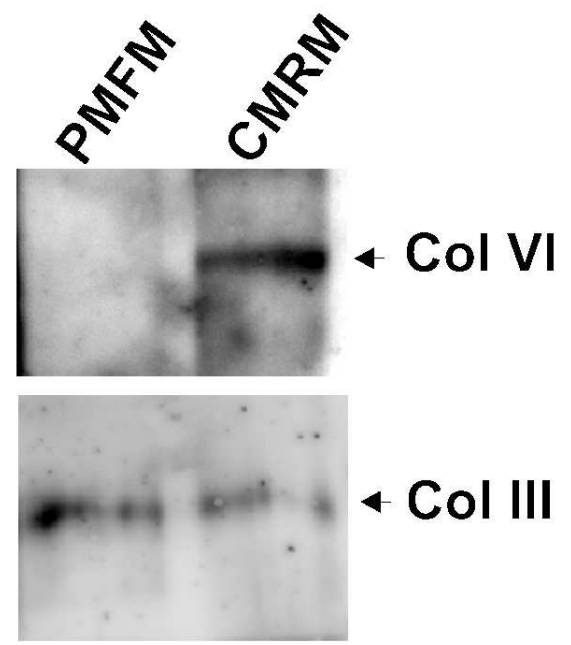

Fig. 4. Immunohistochemistry for collagen type VI $(A, B)$ and Western blotting $(C)$ in proteins from CMRM and PMFM. Collagen type VI shows intense immunoreactivity in CMRM (A), but only moderate staining in PMFM (B). 

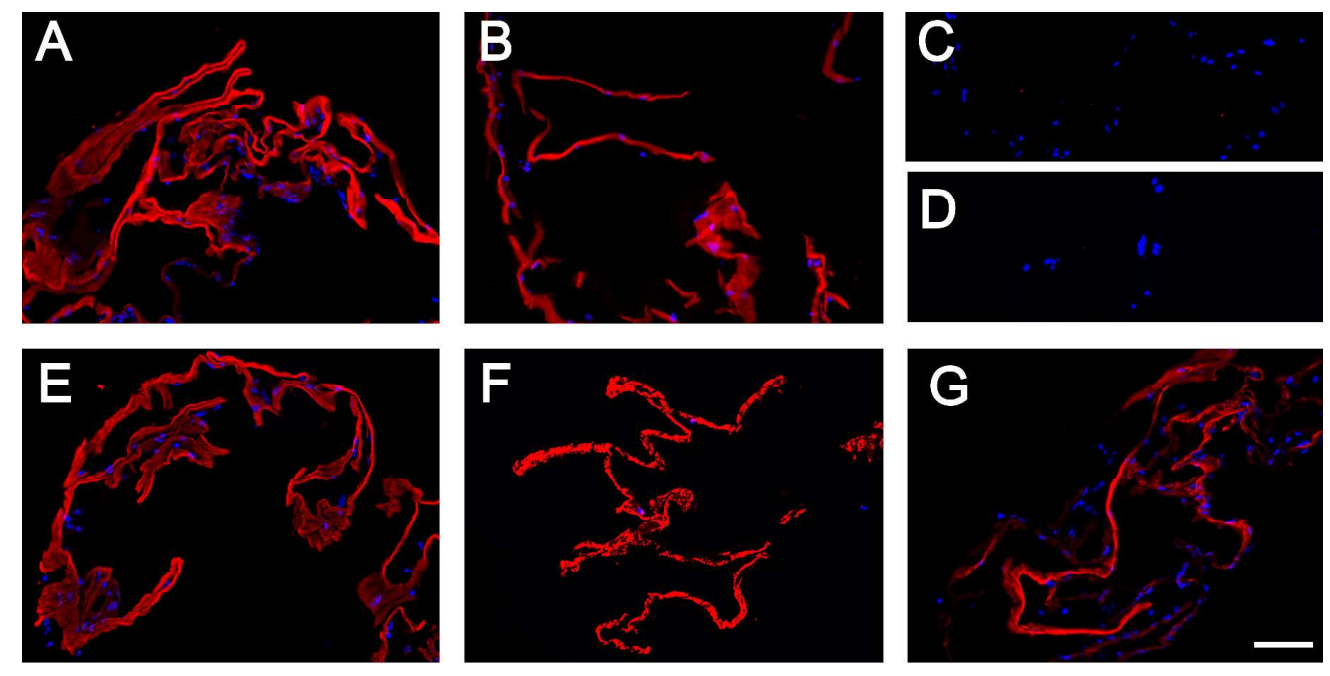

Fig. 5. Immunohistochemistry in CMRM and PMFM. A. collagen I, B. collagen II, E. collagen IV, F. laminin, G. fibronectin (all in PMFM). C, D. Negative controls of secondary antibodies (C. goat antimouse, D. goat anti-rabbit) with omission of primary antibodies show only DAPI-staining of nuclei. Scale bar: $100 \mu \mathrm{m}$.

$155 \times 77 \mathrm{~mm}(600 \times 600 \mathrm{DPI})$ 

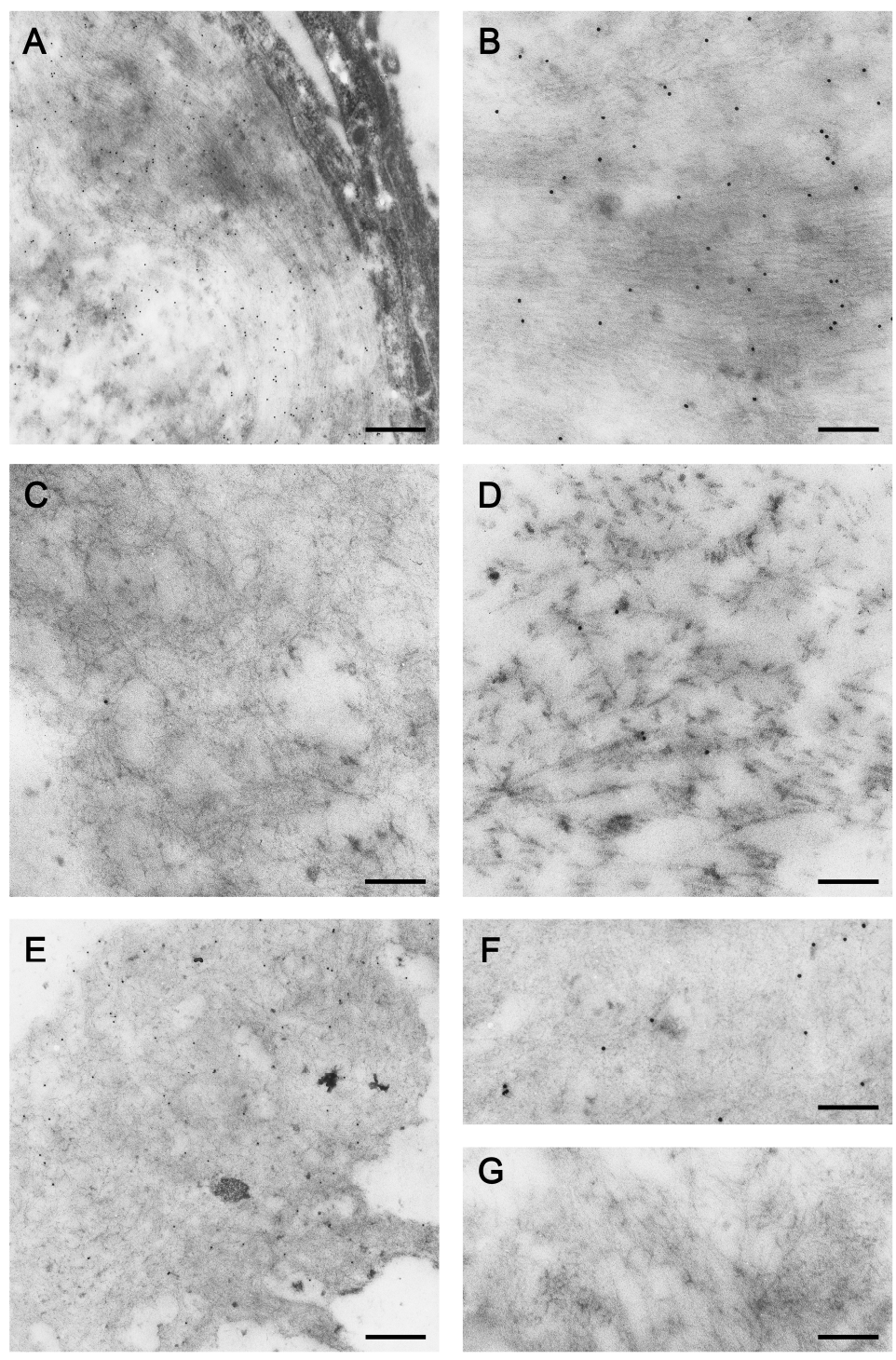

Fig. 6. Immunogold electron microscopy. A-D. Collagen VI. A. Strong expression for collagen VI is seen in the intermediate layer of CMRM, while cells remain unstained (right margin). B. Immungold particles specific for collagen type VI are associated with the 6-15 nm microfibrils in the CMRM. C. Immunoreactivity for collagen type VI is absent in the ILM of CMRM. D. In the intermediate layer of PMFM, only few immungold particles specific for collagen type VI are observed. E,F. Immunogold labeling for collagen type IV in the ILM of PMFM. G. Negative control of secondary antibody with omission of primary antibody. Scale bars $0.5 \mu \mathrm{m}(\mathrm{A}, \mathrm{E}), 1 \mu \mathrm{m}(\mathrm{e}), 200 \mathrm{~nm}(\mathrm{~B}, \mathrm{C}, \mathrm{D}, \mathrm{F}, \mathrm{G})$. $175 \times 270 \mathrm{~mm}(600 \times 600 \mathrm{DPI})$ 

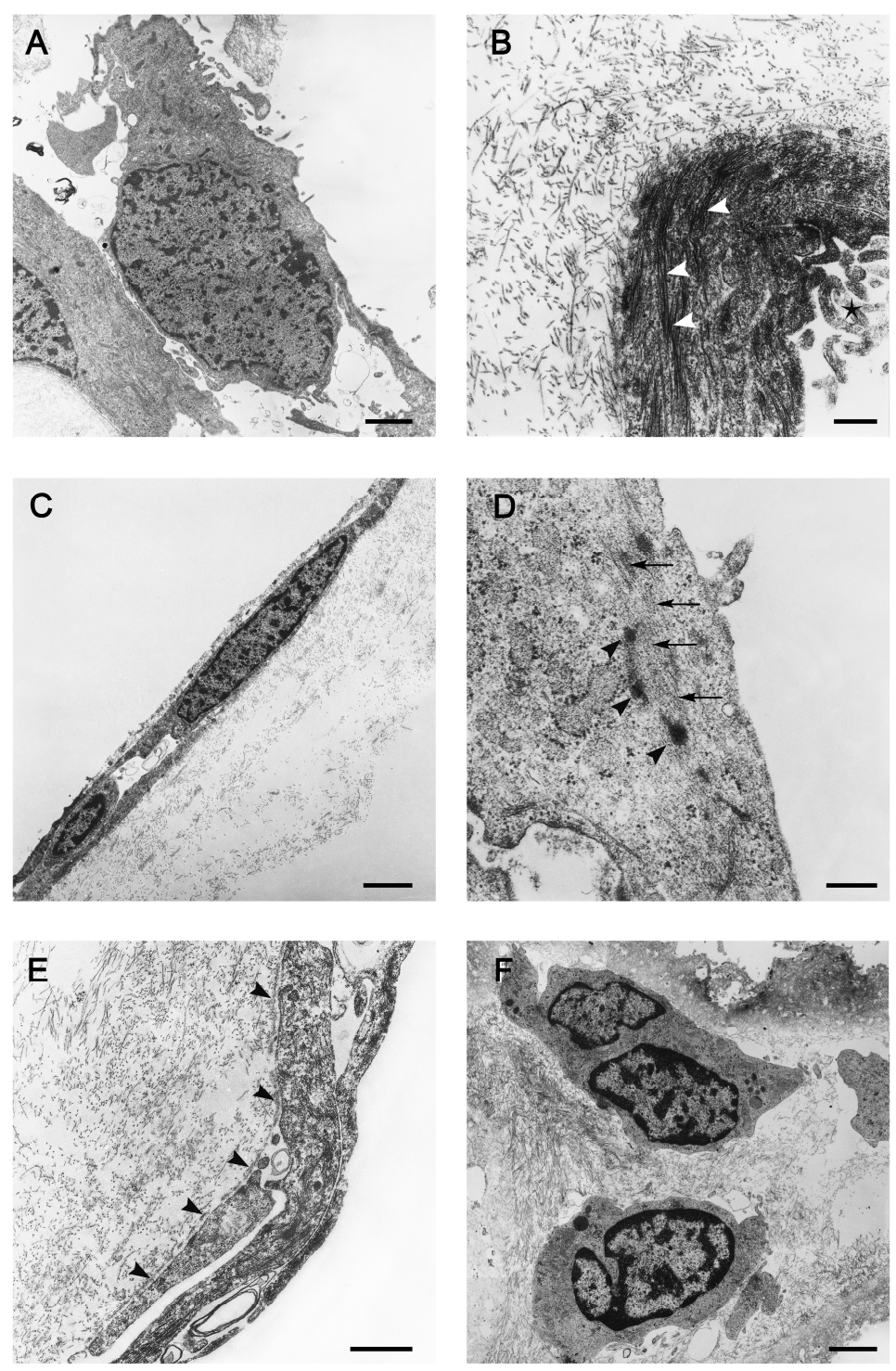

Fig. 7. Electron micrographs of cells in the cellular layer of IEM. A, B. Fibrous astrocytes (A, scale bar: $2 \mu \mathrm{m}$; B. scale bar $0.5 \mu \mathrm{m}$ ) with numerous cellular processes (asterisks in B), and tightly packed intermediate filaments (arrowheads in B). C-E. Myofibroblast-like cells with elongated cells body and oval-shaped nucleus (C, scale bar: $2 \mu \mathrm{m}$ ), and 5-6 nm actin filaments (arrows) with dense bodies (arrowheads, scale bar $0.5 \mu \mathrm{m}$ ). Myofibroblast-like cells are surrounded by basal lamina ( $E$, arrowheads, scale bar $1 \mu \mathrm{m})$. F. Macrophage-like cells in the intermediate layer with indented nuclei and secondary lysosomes, scale bar: $2 \mu \mathrm{m}$. $180 \times 280 \mathrm{~mm}(600 \times 600 \mathrm{DPI})$ 


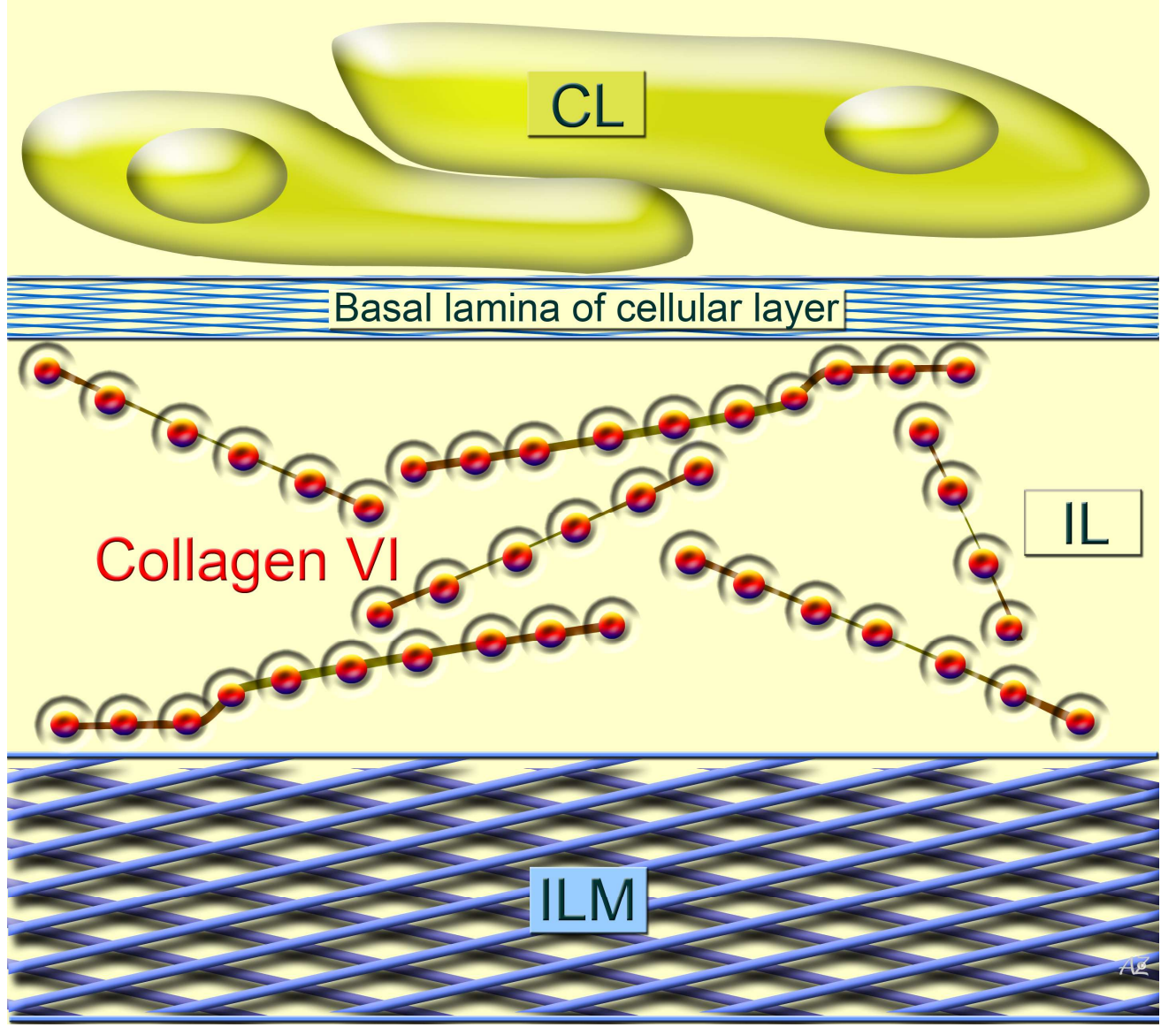

Fig. 8. Schematic drawing of the three-layered structure in CMRM. Collagen type VI fibrils in the intermediate layer (ILM) connect with collagen type IV in the inner limiting membrane (ILM) and with cells and their basal lamina in the cellular layer $(\mathrm{CL})$. $245 \times 218 \mathrm{~mm}(300 \times 300$ DPI $)$ 